\title{
PENERAPAN APLIKASI ANATES BENTUK SOAL PILIHAN GANDA
}

\author{
Muchamad Arif \\ Universitas Trunojoyo Madura \\ Bangkalan, Madura \\ muchamadarif83@yahoo.com
}

\begin{abstract}
Abstrak
Salah satu tugas guru adalah melakukan evaluasi terhadap perangkat tes yang telah dibuatnya, diantaranya adalah analisis butir soal, namun pada kenyataannya tidak banyak yang melaksanakan hal tersebut. Aplikasi anates yang dikembangkan oleh Drs. Karno , M.Pd dan Yusuf Wibisono, ST mencoba membantu mahasiswa dan guru dalam menghitung analisis butir soal dengan tampilan berbahasa Indonesia. Penelitian ini dilakukan pada mahasiswa pendidikan informatika semester 3 yang menempuh mata kuliah evaluasi pendidikan. Metode pengumpulan data yang dilakukan adalah melaui quisoner dengan menggunakan skala likert dan wawancara. Berdasarkan hasil analisis yang dilakukan diketahui bahwa aplikasi anates sangat efektif untuk menghitung analisis butir soal ditinjau dari kemudahan dalam mengoperasikan software sangat efektif, waktu yang dibutuhkan untuk menghitung sangat efektif , efektif pada keakuratan hasil perhitungan analisis butir soal dan sangat efektif dalam memahami output yang dihasilkan.
\end{abstract}

Kata Kunci: Analisi Butir Soal, Anates, Efektifitas.

\begin{abstract}
One of the teachers' tasks is to evaluate the test device that has been made, including the items analysis, but in the reality not much to implement it.. Anates application is developed by Drs. Karno, M. Pd and Yusuf Wibisono, ST tried to help the students and teachers in calculating items analysis by Indonesian. This research was conducted in the third semester of informatics education students who take educational evaluation course. Data collection method is done through questionnaire using Likert scale and interview. Based on the analysis, it is found that Anates application is very effective to calculate the items analysis in terms of ease in operating the software, the time is needed to calculate is very effective on the accuracy results of calculation items analysis in understanding the generated output
\end{abstract}

Keywords: Items analysis, Anates, Effectiveness. 


\section{PENDAHULUAN}

Salah satu tugas seorang guru adalah memberikan penilaian hasil belajar terhadap peserta didiknya. Penilaian adalah upaya atau tindakan untuk mengetahui sejauh mana tujuan yang telah ditetapkan itu tercapai atau tidak. Dengan kata lain, penilaian berfungsi sebagai alat untuk mengtahui keberhasilan proses dan hasil belajar siswa. Penilaian secara umum terbagi menjadi tiga ranah, yakni ranah kognitif, ranah afektif, dan ranah psikomotorik.

Diantara ketiga ranah itu, ranah kognitiflah yang paling banyak dinilai oleh para guru disekolah karena berkaitan dengan kemampuan para siswa dalam menguasai isi bahan pengajaran.

Ada banyak cara yang dilakukan untuk menilai ranah konitif diantaranya melalui ulangan harian,ujian tengah semester, ujian akhir semester dan ujian akhir nasional. Ujian akhir nasional yang di selenggarakan pemerintah pusat berbentuk tes pilihan ganda, oleh karena itu dalam beberapa hal penilaian seorang guru dituntut untuk mampu membuat soal tes pilihan ganda dengan baik dan benar sekaligus mampu mengevaluasi soal tes tersebut apakah digunakan atau tidak untuk tes-tes berikutnya

Soal bentuk pilihan ganda menurut (Surapranata: 2006) adalah soal yang jawabannya harus dipilih dari beberapa kemungkinan jawaban yang telah disediakan. Pilihan ganda adalah salah satu bentuk dari jenis tes obyektif yang pada waktu ini mendapat perhatian dan sering digunakan dalam evaluasi pendidikan. Bila dilihat dari strukturnya, soal pilihan ganda terdiri dari dua bagian, yaitu :
1. Pokok soal (stem) yang berisi permasalahan yang ditanyakan.

2. Sejumlah pilihan atau kemungkinan jawaban (option).

Dari sejumlah pilihan jawaban yang disediakan, hanya ada satu jawaban yang benar, yang disebut kunci jawaban, sedangkan kemungkinan-kemungkinan jawaban yang lain disebut pengecoh (distractor).

Dalam kaidah penulisan soal bentuk pilihan ganda ada beberapa hal yang perlu diperhatikan:

(i) Materi

(ii) Konstruksi

(iii) Bahasa

Kelebihan bentuk tes pilihan ganda menurut Slameto (2001: 63) adalah:

a. Mengukur berbagai jenjang kognitif (dari ingatan sampai dengan evaluasi)

b. Penskorannya mudah, cepat, obyektif, dan dapat mencakup ruang lingkup bahan/materi yang luas dalam suatu tes untuk suatu kelas atau jenjang pendidikan.

c. Bentuk ini sangat tepat untuk ujian yang pesertanya sangat banyak atau yang sifatnya massal, sedangkan hasilnya harus segera diumumkan, seperti ujian semester, ujian sekolah, dan ujian akhir semester.

Sedangkan Keterbatasan bentuk tes pilihan ganda antara lain:

a. Memerlukan waktu yang relatif lama untuk menulis soalnya

b. Sulit membuat pengecoh yang homogen dan berfungsi

c. Terdapat peluang untuk menebak kunci jawaban

Pada umumnya guru berkeyakinan bahwa soal-soal tes yag disusunnya adalah baik, dengan demikian guru berharap hasil 
yang dicapai siswa akan baik pula, namun jika kenyataannya tidak sesuai dengan harapan guru, maka guru perlu menelaah hasil tesnya untuk mengevaluasi kualitas suatu perangkat tes, maupun efektifitas masing-masing butir tes dalam perangkat tes tersebut. Berikut ini akan dijelaskan mengenai analisis butir tes.

1. Taraf kesukaran

Tingkat kesukaran menurut Masriyah (1999: 7) dinyatakan dalam indeks kesukaran (difficulty index) yaitu bilangan yang menunjukkan proporsi siswa yang menjawab benar soal tersebut. Semakin besar indeks kesukaran, semakin mudah butir tersebut. Sebaliknya, semakin kecil indeks kesukaran, semakin sukar butir tersebut. indeks kesukaran suatu butir tes dapat dihitung dengan rumus :

$P=\frac{B_{a}+B_{b}}{J_{a}+J_{b}}$

\section{Keterangan:}

$\mathrm{P}=$ Indeks kesukaran butir tes

$\mathrm{B}_{\mathrm{a}}=$ Banyaknya siswa kelompok atas yang menjawab benar

$\mathrm{B}_{\mathrm{b}}=$ Banyaknya siswa kelompok bawah yang menjawab benar

$\mathrm{J}_{\mathrm{a}}=$ Banyaknya semua siswa kelompok atas

$\mathrm{J}_{\mathrm{b}}=$ Banyaknya semua siswa kelompok bawah

Tabel 1. Kriteria indek kesukaran

\begin{tabular}{|l|l|}
\hline $\begin{array}{l}\text { Indeks } \\
\text { Kesukaran }\end{array}$ & $\begin{array}{l}\text { Penafsiran } \\
\text { butir soal }\end{array}$ \\
\hline $\mathrm{P}<0.30$ & Soal sukar \\
\hline $0.30 \leq \mathrm{P} \leq$ & Soal sedang \\
0.70 & \\
\hline $\mathrm{P}>0.70$ & Soal mudah \\
\hline
\end{tabular}

2. Indeks daya pembeda

Daya pembeda butir tes menurut Ratumanan (2003: 70) menyatakan seberapa jauh kemampuan butir tersebut mampu membedakan antara kelompok siswa pandai dengan kelompok lemah. daya pembeda butir tes dihitung dengan rumus:

$D=P_{a}-P_{b}$

\section{Keterangan:}

$\mathrm{D}$ = indeks daya pembeda

$\mathrm{P}_{\mathrm{a}}=$ proporsi siswa kelompok atas yang menjawab benar butir tes $\left(=\frac{B_{a}}{J_{a}}\right)$

$\mathrm{P}_{\mathrm{b}}=$ proporsi siswa kelompok bawah yang menjawab benar butir tes $\left(=\frac{B_{b}}{J_{b}}\right)$

Tabel 2. Kriteria daya pembeda

\begin{tabular}{|l|l|}
\hline $\begin{array}{l}\text { indeks daya } \\
\text { pembeda }\end{array}$ & $\begin{array}{l}\text { Penafsiran butir } \\
\text { soal }\end{array}$ \\
\hline $\mathrm{D}>0.40$ & Sangat baik \\
\hline $0.30<\mathrm{D} \leq$ & Baik \\
0.40 & \\
\hline $0.20<\mathrm{D} \leq$ & Cukup \\
0.30 & \\
\hline $\mathrm{D} \leq 0.20$ & Jelek \\
\hline
\end{tabular}

3. Analisis distraktor

Untuk mengetahui keefektifan tiap option soal dapat dilakukan dengan menghitung berapa banyak siswa yang memilih option tersebut. Selain itu dapat dilihat pengecoh mana yang berfungsi efektif, pengcoh mana yang tidak efektif, dan pengecoh mana yang menyesatkan. Jika ternyata lebih banyak siswa yang memilih suatu pengecoh tertentu dan hanya sedikit yang memilih kunci, maka ada kemungkinan penilai salah membuat kunci jawaban, dan mungkin pengecoh tersebut sebenarnya adalah kunci jawaban. Namun mungkin pula kuncinya sudah benar, tetapi pengecoh terlalu menarik untuk dipilih.. 
Menurut Masriyah (1999: 22) jika ditinjau dari pemilih kelompok atas dan kelompok bawah, maka :

(i) Pengecoh efektif jika $\mathrm{N}_{\mathrm{a}}<\mathrm{N}_{\mathrm{b}}$

(ii) Pengecoh menyesatkan jika $\mathrm{N}_{\mathrm{a}}>$ $\mathrm{N}_{\mathrm{b}}$

(iii) Pengecoh tidak efektif jika $\mathrm{N}_{\mathrm{a}}=\mathrm{N}_{\mathrm{b}}$ Ket : $\mathrm{N}_{\mathrm{a}}=$ banyaknya siswa kelompok atas yang memilih pengecoh

$\mathrm{N}_{\mathrm{b}}=$ banyaknya siswa kelompok bawah yang memilih pengecoh

\section{Reliabilitas}

Reliabilitas suatu tes menurut Masriyah (1999: 9) adalah tingkat keajegan atau kestabilan dari hasil pengukuran. Alat ukur yang reliabel adalah alat ukur yang apabila digunakan untuk mengukur hal yang sama berulang-ulang, hasilnya relatif sama. Reliabilitas suatu tes pada umumnya dinyatakan dengan koefisien reliabilitas atau kesalahan pengukuran standard yang dihitung berdasarkan koefisien reliabilitas.Salah satu cara untuk mencari besarnya koefisien reliabilitas adalah dengan menggunakan metode belah dua, pada metode ini untuk mengetahui reliabilitas seluruh tes digunakan rumus Spearman-Brown sebagai berikut : $\quad r_{t t}=\frac{2 r_{1 / 21 / 2}}{1+\left|r_{1 / 21 / 2}\right|}$

Sedangkan $r_{1 / 2 / 2}$ dapat dihitung dengan menggunakan rumus korelasi product moment sebagai berikut :

$r_{1 / 2 / 2}=\frac{N \sum X Y-\left(\sum X\right)\left(\sum Y\right)}{\sqrt{\left(N \sum X^{2}-\left(\sum X\right)^{2}\right)\left(N \sum Y^{2}-\left(\sum Y\right)^{2}\right)}}$

\section{Keterangan:}

$\mathrm{r}_{\mathrm{tt}}=$ koefisien reliabilitas tes

$r_{1 / 21 / 2}=$ koefisien reliabilitas separuh tes

$\mathrm{X}=$ skor ganjil

$\mathrm{Y}=$ skor genap

$\mathrm{N}$ = banyak siswa

\section{Validitas Butir (Item Validity)}

Menurut Masriyah (1999: 23) suatu butir tes dikatak valid jika mempunyai dukungan yang besar terhadap skor total. Skor pada tiap tes dapat menyebabkan skor total menjadi tinggi atau rendah. Dengan kata lain, suatu butir tes memiliki validitas tinggi jika skor pada butir tersebut mempunyai kesejajaran dengan skor total. Kesejajaran ini dapat diartikan dengan korelasi sehingga untuk mengetahui validitas buitr tes digunakan rumus korelasi. Untuk soal-soal bentuk obyektif, biasanya diberikan skor 1 (untuk jawaban benar), atau skor 0 (untuk jawaban salah), sedangkan skor totalnya diperoleh dari menjumlahkan skor tiap butir yang membangun perangkat tes tersebut. Untuk menentukan besarnya koefisien korelasi dapat digunakan rumus korelasi product moment yaitu :

$$
\begin{aligned}
r_{x y} & =\frac{N \sum X Y-\left(\sum X\right)\left(\sum Y\right)}{\sqrt{\left(N \sum X^{2}-\left(\sum X\right)^{2}\right)\left(N \sum Y^{2}-\left(\sum Y\right)^{2}\right)}} \\
\text { Dengan: } &
\end{aligned}
$$

$r_{x y}=$ koefisien korelasi product

moment

$\mathrm{X}=$ skor butir

$\mathrm{Y}=$ skor total

$\mathrm{N}=$ banyaknya peserta tes

Kriteria validitas butir $\left(r_{x y}\right)$ (Arikunto, 2005)adalah sebagai berikut: 
Tabel 3. Kriteria validitas butis soal

\begin{tabular}{|c|c|}
\hline Validitas butir & Kriteria Validitas Butir \\
\hline $\begin{array}{l}0.80 \leq r_{x y} \leq \\
1.00\end{array}$ & $\begin{array}{l}\text { validitas butir } \\
\text { sangat tinggi }\end{array}$ \\
\hline $\begin{array}{l}0.60 \leq \mathrm{r}_{\mathrm{xy}} \leq \\
0.79\end{array}$ & validitas butir tes tinggi \\
\hline $\begin{array}{l}0.40 \leq r_{x y} \leq \\
0.59\end{array}$ & $\begin{array}{l}\text { validitas } \\
\text { cukup }\end{array}$ \\
\hline $\begin{array}{l}0.20 \leq r_{x y} \leq \\
0.39\end{array}$ & $\begin{array}{l}\text { validitas butir } \\
\text { rendah }\end{array}$ \\
\hline $\begin{array}{l}0.00 \leq \mathrm{r}_{\mathrm{xy}} \leq \\
0.19\end{array}$ & $\begin{array}{l}\text { validitas butir } \\
\text { sangat rendah }\end{array}$ \\
\hline
\end{tabular}

Untuk menghitung kelima poin diatas biasanya guru atau mahasiswa menghitung seecara manual menggunakan alat bantu kalkulator atau ms excel. Seiring dengan perkembangan teknologi diciptakannya aplikasi untuk menghitung analisis butir soal yaitu Anates.Anates merupakan program aplikasi yang dikembangkan oleh Drs.Karno M.Pd dan Yusuf Wibisono, ST mampu menghitung analisis butir soa secara cepat,mudah dan akurat, apalagi aplikasi ini berbahasa indonesia.Anates mampu menampilkan bebrapa fitur dan perhitungan diantaranya: Skor data dibobot, Reabilitas Tes, Kelompok atas dan Kelompok bawah, Daya pembeda, tingkat Kesukaran, Korelasi skor butir dengan skor total dan kualitas pengecoh.

Penelitian ini mencoba mengukur keefektifan aplikasi anates. Efektivitas memiliki arti berhasil atau tepat guna. Efektif merupakan kata dasar, sementara kata sifat dari efektif adalah efektivitas. Menurut Effendy (1989) mendefinisikan efektivitas sebagai berikut: "Komunikasi yang prosesnya mencapai tujuan yang direncanakan sesuai dengan biaya yang dianggarkan, waktu yang ditetapkan dan jumlah personil yang ditentukan" (Effendy, 1989:14). Efektivitas menurut pengertian di atas mengartikan bahwa indikator efektivitas dalam arti tercapainya sasaran atau tujuan yang telah ditentukan sebelumnya merupakan sebuah pengukuran dimana suatu target telah tercapai sesuai dengan apa yang telah irencanakan. Pengertian efektifan menurut Mahmudi (2005:92) adalah merupakan hubungan antara output dengan tujuan, semakin besar kontribusi (sumbangan) output terhadap pencapaian tujuan, maka semakin efektif organisasi, program atau kegiatan. Sedangkan ukuran efektivitas penerapan sistem informasi berbasis computer antara lain variabel keamanan data, waktu, ketelitian, relevansi, variasi laporan dan kenyamanan fisik (Bodnar dan Hopwood, 2006), variabel kualitas informasi (Manuaba, 2010), dan variabel teknologi informasi (Adinata, 2011)

Keefektifan yang ingin kita tinjau pada penerapan aplikasi Anates ini adalah waktu yang dibutukan untuk menganalisis, keakuratan hasil analisis, kemudahan pengoprasian, dan kemudahan dalam membaca print out.

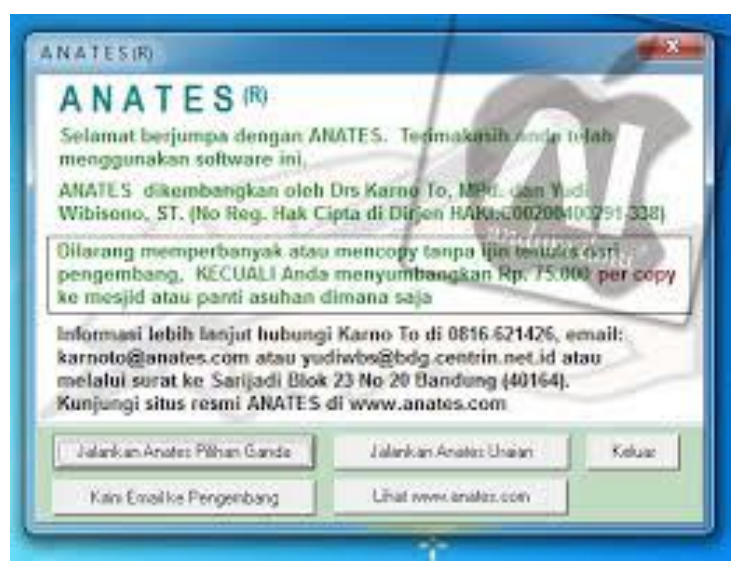

Gambar 1. Tampilan awal anates 


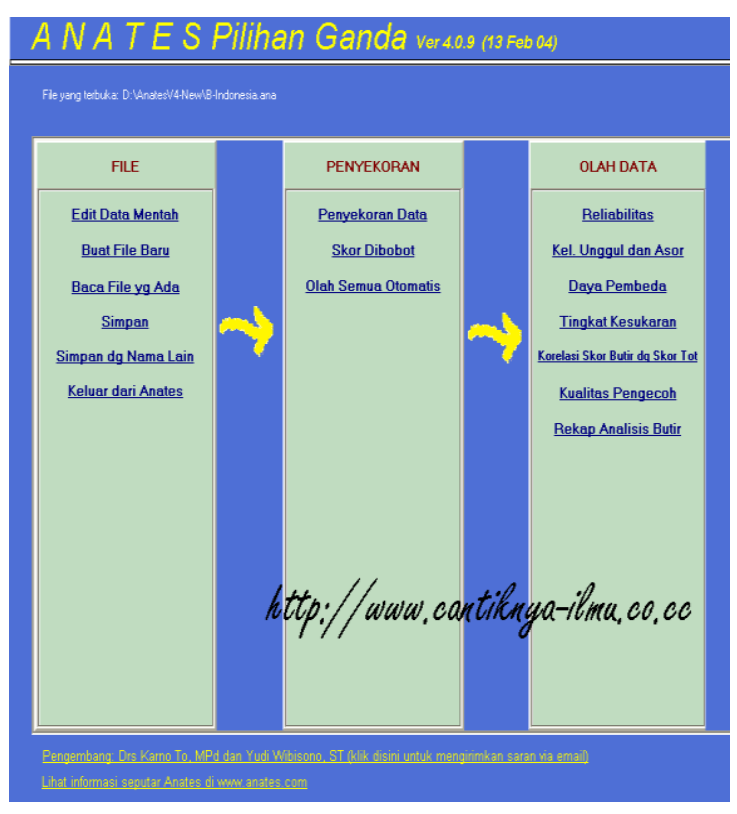

Gambar 2. Anates pilihan ganda

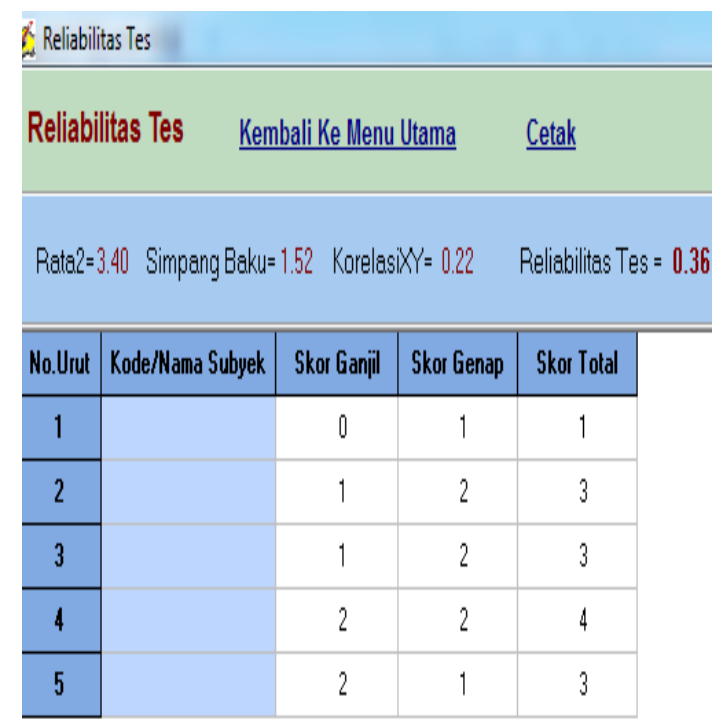

Gambar 3. Reabilitas tes

\section{METODE PENELITIAN}

Aplikasi Anates akan diuji keefektifannya pada mahasiswa pendidikan informatikia Universitas Trunojoyo Madura yang sedang menempuh mata kuliah evaluasi pendidikan. Sampel yang diambil adalah kelas 3b semester 3. Dalam menghitung analisis butir soal mereka selama ini menghitung secara manual dengan bantuan program Ms.Exel Data yang digunakan dalam penelitian ini adalah data kuantitatif berupa hasil jawaban quisoner semua mahasiswa kelas $3 \mathrm{~b}$ pendidikan informatika sebanyak 41 orang dan data kualitatif berupa hasil wawancara dengan lima mahasiswa kelas $3 b$ pendidikan informatika.

Validasi instrumen quisoner dan wawancara menggunakan validasi teoritik yaitu validitas alat evaluasi yang ditentukan berdasarkan pertimbangan pakar atau ahli. Bagian dari butir tes yang perlu divalidasi adalah dari segi materi, konstruk, dan bahasa.

Cara pengisian quisoner yang dilakukan mahasiswa adalah memeberi tanda centang pada skala yang didentukan sesuai dengan pertanyaan yang ada. Teknik analisi data yang digunakan adalah dengan menggunakan teknik analisis kuantitatif dan pengukuran dilakukan dengan menggunakan skala likert. Menurut Sugiono (93: 2012 ) menjelaskan bahwa skala likert digunakan untuk mengukur sikap, pendapat dan persepsi seseorang atau kelompok orang mengenai fenomena sosial. Banyaknya jenjang skala likert pada quisoner yang digunakan sebanyak 4 yaitu sangat setuju, setuju, tidak setuju dan sangat tidak setuju. Dengan masing-masing skor pada pilihan pertama diberi skor 4, pilihan kedua diberi skor 3, pilihan ketiga diberi skor 2, dan pilihan keempat diberi skor 1. Sedangkan skala likert yang untuk mengetahui sikap responden terhadap masing masing butir pertanyaan yang mereka isi dalam quisoner mengetahui keefektifan aplikasi anates adalah sebagai berikut:

1. Menentukan skor maksimal, yaitu skor jawaban terbesar dikali banyaknya responden 
2. Menentukan skor minimal, yaitu skor terkecil dikali banyaknya responden

3. Menentukan nilai median yaitu hasil penjumlahan skor maksimal dengan skor minimal dibagi dua

4. Menentukan nilai kuartil 1, yaitu hasil penjumlahan skor minimal dengan median dibagi dua

5. Menentukan nilai kuartil 3, yaitu hasil penjumlahan skor maksimal dengan median dibagi dua

6. Membuat skala yang menggambarkan skor minimal, kuartil satu, median, kuartil 3 dan skor maksimal

a. Kategori tiap butir pertanyaan sangat efektif jika mendapat skor yang dibatasi oleh skor

kuartil 3 dan skor maksimal. (Kuartil $3 \leq \mathrm{x} \leq$ skor maksimal)

b. Kategori tiap butir pertanyaan efektif jika mendapat skor yang dibatasi oleh skor median dan skor kuartil 3. (median $3 \leq \mathrm{x} \leq$ kuartil 3).

c. Kategori tiap butir pertanyaan tidak efektif jika mendapat skor yang dibatasi oleh skor kuartil 1 dan skor median. (Kuartil $1 \leq \mathrm{x} \leq$ skor median)

d. Kategori tiap butir pertanyaan sangat tidak efektif jika mendapat skor yang dibatasi oleh skor minimal dan skor kuartil 1. (skor minimal $\leq \mathrm{x} \leq$ kuartil 1 )

7. Menentukan batas -batas skor untuk masing-masing kategori keefektifan berdasarkan skala yang sudah dibuat

8. Membuat kesimpulan untuk masingmasing butir pertanyaan

Sedangkan untuk menyimpulkan secara keseluruhan keefektifan penerapan aplikasi anates adalah dengan menjumlahkan seluruh skor butir pertanyaan kemudian dibuat kategori keefektifan seperti pada nomor 6 .

Sedangkan analisis kualitatif berupa wawancara secara selain untuk mengetahui keefektifan penerapan aplikasi anates juga untuk mengetahui kelemahan-kelemahan aplikasi anates.

\section{HASIL DAN PEMBAHASAN}

Dengan jumlah sampel sebanyak 41 mahasiswa dan dengan menggunakan skala likert terhadap masing masing butir pertanyaan diperoleh data sebagai berikut:

1. Nilai skor maksimal sebesar 164

2. Nilai skor kuartil 3 sebesar 133,25

3. Nilai skor median sebesar 102,5

4. Nilai skor kuartil 1 sebesar 71,75

5. Nilai skor minimal sebesar 41

Berdasarkan data tersebut maka dapat disimpulkan:

a. Kategori tiap butir pertanyaan sangat efektif jika mendapat skor 133,25 $\leq \mathrm{x} \leq$ 164

b. Kategori tiap butir pertanyaan efektif jika mendapat skor 102,5 $\leq \mathrm{x} \leq 133,25$

c. Kategori tiap butir pertanyaan tidak efektif jika mendapat skor $71,75 \leq \mathrm{x} \leq$ 102,5

d. Kategori tiap butir pertanyaan sangat tidak efektif jika mendapat skor $41 \leq$ $\mathrm{x} \leq 71,75$

Sedangkan untuk mengukur keefektifan secara keseluruhan diperoleh data sebagai berikut:

1. Nilai skor maksimal sebesar 1640

2. Nilai skor kuartil 3 sebesar 1332,5

3. Nilai skor median sebesar 1025

4. Nilai skor kuartil 1 sebesar 717,5

5. Nilai skor minimal sebesar 410

Berdasarkan data tersebut maka dapat disimpulkan: 
a. Aplikasi anates dikategorikan sangat efektif jika mendapat skor $1332,5 \leq \mathrm{x}$ $\leq 1640$

b. Aplikasi anates dikategorikan efektif jika mendapat skor $1025 \leq \mathrm{x} \leq 1332,5$

c. Aplikasi anates dikategorikan tidak efektif jika mendapat skor $717,5 \leq \mathrm{x} \leq$ 1025

d. Aplikasi anates dikategorikan sangat tidak efektif jika mendapat skor $410 \leq$ $\mathrm{x} \leq 717,5$

Dari hasil perhitungan diperoleh data tiap butir pertanyaan sebagi berikut:

1. Dari data tentang minat mahasiswa dalam mengunakan aplikasi anates diperoleh skor 142 sehingga termasuk kategori sangat efektif

2. Dari kemudahan mahasiswa dalam mengoperasikan aplikasi anates diperoleh skor 144 sehingga termasuk kategori sangat efektif

3. Dari kecepatan aplikasi anates dalam mengolah analisis butir soal diperoleh skor 141 sehingga termasuk kategori sangat efektif

4. Dari keakuratan aplikasi anates dalam menghitung validitas diperoleh skor 138 sehingga termasuk kategori sangat efektif

5. Dari keakuratan aplikasi anates dalam menghitung reabilitas diperoleh skor 132 sehingga termasuk kategori efektif

6. Dari keakuratan aplikasi anates dalam menghitung daya pembeda diperoleh skor 131 sehingga termasuk kategori efektif

7. Dari keakuratan aplikasi anates dalam menghitung taraf kesukaran diperoleh skor 135 sehingga termasuk kategori sangat efektif

8. Dari keakuratan aplikasi anates dalam menghitung keefektifan option diperoleh skor 132 sehingga termasuk kategori efektif

9. Dari hasil output aplikasi anates tannpa mengetahui rumus untuk mencari analisis butir soal diperoleh skor 108 sehingga termasuk kategori efektif

10. Dari kejelasan dalam membaca hasil out aplikasi anates diperoleh skor 135 sehingga termasuk kategori efektif

Berdasarkan hasil keseluruhan perhitungan dari seluruh butir pertanyaan yang diajukan dalam kuisoner diperoleh skor total sebesar 1338 sehingga secara umum responden memandang aplikasi anates sangat efektif dalam menghitung analisis butir soal.

Sedangkan dari hasil wawancara diperoleh kelemahan dan kelebihan aplikasi anates sebagai berikut:

1. Belum bisa menghitung reabilitas untuk masing-masing soal

2. Tidak menampilkan rumus untuk menghitung analisis butir soal

3. Tidak menampilkan langkah-langkah dalam menyusun analisis butir soal

4. Kategori yang disusun dalam analisis butir soal mengalami perdaan dengan beberapa sumber acuan yang dipakai mahasiswa misalnya keefektifan option pada anates menampilkan kategori sangat baik, baik, kurang baik, buruk dan sangat buruk. Pada beberapa sumber buku kategori keefektifan option adalah menyesatkan, efektif dan tidak menyesatkan

5. Salah satu kelebihannya adalah tampilan berbahasa Indonesia sehingga memudahkan dalam penggunaannya

6. Hasil output analisis butir soal cukup akurat 


\section{KESIMPULAN DAN SARAN}

Berdasarkan hasil penelitian diperoleh aplikasi anates dalam menghitung analisis butir soal sangat efektif sehingga dapat membantu mahasiswa dan guru pada umumnya dalam mengevaluasi soal tes yang mereka buat tampilan berbahasa Indonesia menjadi nilai tambah buat aplikasi anates disbanding dengan software yang sudah ada semisal spss, namun alangkah baiknya dalam aplikasi ditunujukan rumus untuk menghitung analisis butir soal sehingga mahasiswa maupun guru lebih mudah memahami dan memang ada beberapa formula yang berbeda untuk menghitung analisis butir soal meskipun hasil akhirnya tidak jauh berbeda.

DAFTAR PUSTAKA

Arikunto, Suharsimi. 2005. Dasar-Dasar Evaluasi Pendididikan. Jakarta : Bumi Aksara

Adinata, Kadek Bagus Wira. 2011. Penilaian Efektivitas Sistem Informasi Akuntansi pada Perusahaan Daerah Air Minum di Kabupaten Badung. Skripsi Sarjana Akuntansi Fakultas Ekonomi Universitas Udayana.

Bodnar, George H. dan Hopwood, William S. (Amir Abadi Jusuf dan Rudi M

Tambunan, Penerjemah). 2000. Sistem Informasi Akuntansi. Edisi Keenam. Jakarta: Salemba Empat.

Effendy, O.U.2005. Ilmu Komunikasi Teori dan Praktek. Bandung: PT Remaja Rosdakarya.
Mahmudi. (2005). Manajemen Kinerja Sektor Publik. Yogyakarta: UPP AMP YKPN.

Manuaba, IB Gde Suryadana. 2010. Persepsi Pemakai Informasi dan Pengolahan Data terhadap Efektivitas Pengolahan Data Elektronik (PDE) pada PT. Agung Automall di Bali. Skripsi Sarjana Akuntansi Fakultas Ekonomi Universitas Udayana.

Masriyah. 1999. Validitas dan Realibilitas. Surabaya : Unesa University Press

\begin{tabular}{l}
\hline 1999. Analisis Butir Tes. \\
Surabaya : Unesa University Press
\end{tabular} Mulyadi. 2001. Sistem Akuntansi. Edisi Ketiga. Jakarta: Salemba Empat

Ratumanan, Tanwey Gerson. 2003. Evaluasi Hasil Belajar yang relevan dengan kurikulum berbasis kompetensi. Surabaya : Unesa University Press

Riduwan, Dr. 2012. Skala Pengukuran Variabel-Variabel Penelitian. Jakarta:Alfabeta

Slameto. 2003. Belajar dan Faktor-Faktor yang mempengaruhinya.Jakarta: Rineka Cipta.

Supranata.2005. Panduan Penulisan Tes Tertulis.Bandung: Remaja Rosdakarya. 